\title{
PENGARUH STRUKTUR MODAL TERHADAP NILAI PERUSAHAAN PADA PERUSAHAAN TEKSTIL DAN GARMEN
}

\author{
Fairuz Khoirunnisa \\ Universitas Pendidikan Indonesia \\ fairuz.khoirunnisa96@student.upi.edu \\ Imas Purnamasari \\ Universitas Pendidikan Indonesia \\ imaspurnamasari@upi.edu \\ Heraeni Tanuatmodjo \\ Universitas Pendidikan Indonesia \\ heraenitanuatmodjo@upi.edu
}

\begin{abstract}
ABSTRAK
Tujuan - Tujuan dari penelitian ini adalah untuk mengetahui bagaimana gambaran strukur modal dan nilai perusahaan serta menganalisis pengaruh struktur modal terhadap nilai perusahaan pada perusahaan tekstil dan garmen periode 2011-2015

Desain / metodologi / pendekatan - Metode yang digunakan dalam penelitian ini adalah metode deskriptif dan verifikatif. Data yang digunakan adalah data sekunder dari fact book tahunan dengan teknik analisis regresi linear sederhana. Teknik pengambilan sampel dalam penelitian ini menggunakan purposive sampling.

Temuan - Hasil penelitian menunjukkan bahwa struktur modal memiliki pengaruh positif terhadap nilai perusahaan.

Orisinalitas - Perbedaan penelitian dengan penelitian sebelumnya adalah pada objek, populasi dan sampel penelitian, periode penelitian, alat ukur dan hasil penelitian.
\end{abstract}

Kata kunci: Strukur Modal, Nilai Perusahaan, Tekstil dan Garmen

Pasal Jenis: Penelitian Studi Kasus

\begin{abstract}
Purpose - The purpose of this research are to descript of capital structure and firm value, and to analyze the impact of capital structure to firm value at textile and garment companies for the period 2011 2015.

Design / methodology / approach - Method in this research used descriptive and verification methods. Data that used are secondary data from fact book years 2011-2015 with analysis technique using simple linear regression. Sampling in this research use purposive sampling.

Findings - The result showed that the capital structure has a positive effect to firm value.

Originality -The difference of this research with previous research is on research object, population and research sample, research period, measuring instrument and research result.
\end{abstract}

Keywords : Capital Structure, Firm Value, Subsector Textile and Garment.

Article Type: Case Study paper

\section{PENDAHULUAN}

Perusahaan memiliki tiga tujuan utama yaitu menghasilkan laba atau keuntungan yang sebesar-besarnya (Diani, 2015; Husnan \& Pudjiastuti, 2006), mengoptimalkan kesejahteraan pemilik perusahaan (Diani, 2015; Mardiyati, Ahmad, \& Putri, 2012), dan menaikkan nilai perusahaannya (Sunyoto \& Susanti, 2015). Nilai perusahaan sangat penting karena mencerminkan kinerja perusahaan yang dapat mempengaruhi persepsi investor terhadap perusahaan dan prospek perusahaan di masa mendatang (Jayaningrat, Wahyuni, \& Sujana, 2017; Suharli, 2006).

Semakin tinggi nilai perusahaan menandakan tingginya kinerja perusahaan yang berarti semakin besar pula kemakmuran yang akan diterima oleh pemilik perusahaan sehingga pemilik perusahaan tertarik untuk 
menginvestasikan modalnya pada perusahaan tersebut (Husnan \& Pudjiastuti, 2006; Solikin, Widaningsih, \& Lestari, 2015; Sunyoto \& Susanti, 2015).

Nilai perusahaan yang sudah go public di pasar modal tercermin dalam harga saham, jika harga sahamnya meningkat maka nilai perusahaan pun meningkat (Diani, 2015; Husnan \& Pudjiastuti, 2006), sedangkan perusahaan yang belum go public nilainya tercermin pada nilai aset perusahaan, tingkat risiko usaha, prospek perusahaan, manajemen, lingkungan usaha, dan faktor-faktor lainnya (Mardiyati et al., 2012; Sunyoto \& Susanti, 2015). Dalam perusahaan yang menerbitkan saham, umumnya nilai perusahaan diproksi oleh Price Book Value (PBV) atau nilai buku perusahaan yang dapat membuat pasar percaya atas prospek perusahaan (Diani, 2015; Tobing, 2015).

Rasio PBV yang dianalisis merupakan perbandingan antara harga saham pada suatu periode dengan nilai buku ekuitas yang diperoleh dari neraca perusahaan pada periode tertentu. Semakin tinggi rasio PBV menunjukkan bahwa pasar percaya terhadap prospek perusahaan tersebut (Darmadji \& Fakhruddin, 2011). Rasio PBV menggambarkan besarnya penghargaan investor terhadap nilai buku saham suatu perusahaan, semakin tinggi rasio $\mathrm{PBV}$ maka semakin tinggi apresiasi pasar terhadap prospek perusahaan. Jika sebuah perusahaan memiliki tingkat pengembalian yang rendah atas aktivitasnya maka rasio PBV juga akan relatif rendah terhadap rata-rata perusahaan. Pertumbuhan perusahaan yang baik mempunyai rasio PBV lebih dari satu dan menunjukkan bahwa investor bersedia membayar lebih untuk saham daripada nilai bukunya. Sebaliknya jika PBV kurang dari satu menunjukkan nilai buku per lembar saham lebih besar dari nilai pasar per lembar saham (Simatupang, 2010; Suta, Agustina, \& Sugiarta, 2016).

Sektor yang memiliki PBV di bawah satu selama kurun waktu tiga tahun berturut-turut adalah sektor Aneka Industri. Aneka Industri merupakan sektor yang termasuk ke dalam sektor sekunder (industri pengolahan atau manufaktur) berdasarkan JASICA (Jakarta Industrial Classification) (Zulfikar, 2016).
Tabel 1

PBV Sektor Aneka Industri Periode 2011-2015

\begin{tabular}{cccccc}
\hline SUBSEKTOR & $\mathbf{2 0 1 1}$ & $\mathbf{2 0 1 2}$ & $\mathbf{2 0 1 3}$ & $\mathbf{2 0 1 4}$ & $\mathbf{2 0 1 5}$ \\
\hline $\begin{array}{c}\text { Mesin dan Alat } \\
\text { Berat }\end{array}$ & - & - & 1.82 & 4.21 & - \\
Otomotif dan & & & & & \\
Komponennya & 1.71 & 1.72 & 1.47 & 1.52 & 1.42 \\
$\quad$ Tekstil dan & 0.95 & 0.68 & 0.42 & 0.48 & 0.75 \\
$\quad$ Garmen & & & & & \\
Alas Kaki & -0.40 & 0.80 & 1.59 & 1.52 & 0.99 \\
$\quad$ Kabel & 0.81 & 1.16 & 1.15 & 0.99 & 0.72 \\
Elektronika & 0.33 & 0.34 & 0.23 & 0.25 & 0.20 \\
Lainnya & - & - & - & - & - \\
\hline \multicolumn{5}{l}{ Sumber: IDX Fact Book, diunduh dari www.idx.co.id(data diolah) }
\end{tabular}

Pada tabel 1 terlihat bahwa terdapat lima subsektor yang memiliki PBV selama periode 2011-2015, yaitu subsektor Otomotif dan Komponennya, Tekstil dan Garmen, Alas Kaki, Kabel, dan Elektronika. Subsektor Mesin dan Alat Berat tidak memiliki PBV pada tahun 2011, 2012, dan 2015. Subsektor Lainnya tidak memiliki PBV selama periode 2011-2015. PBV tertinggi dimiliki oleh subsektor Otomotif dan Komponennya sedangkan subsektor yang memiliki PBV terendah adalah subsektor Elektronika. Subsektor Tekstil dan Garmen yang memiliki kontribusi besar terhadap perekonomian Indonesia sebagai penyerap tenaga kerja dan penyumbang devisa ekspor memiliki PBV yang rendah yaitu di bawah satu. PBV rendah yang dimiliki oleh subsektor Tekstil dan Garmen menunjukkan harga pasar saham lebih murah daripada harga nominalnya. Hal tersebut tentu sangat berisiko karena saham subsektor Tekstil dan Garmen kurang dihargai oleh masyarakat atau undervalued yang berdampak pada berkurangnya investasi dari investor dan menjadi permasalahan yang sangat penting sehingga perlu dilakukan penanggulangan agar nilai perusahaan pada subsektor Tekstil dan Garmen kembali meningkat.

Naik turunnya nilai perusahaan dapat disebabkan beberapa hal antara lain: likuiditas (Du, Wu, \& Liang, 2016; Nguyen, Duong, \& Singh, 2016), profitabilitas (Al-Najjar, 2017), pembayaran dividen (Seth \& Mahenthiran, 2016; Sulong \& Nor, 2008; Widyastuti, Suhadak, Musadieq, \& Hsu, 2016), tata kelola perusahaan (Ararat, Black, \& Yurtoglu, 2016; Khan, Tanveer, \& Malik, 2017; Sulong \& Nor, 2008), manajemen pajak (Davis, Moore, \& Rupert, 2016; Nesbitt, Outslay, \& Persson, 2017), kinerja keuangan (Widyastuti et al., 2016), pengambilan risiko ( $\mathrm{Su}$, Li, \& Wan, 2016), pembiayaan eksternal dan ukuran perusahaan (Al-Najjar, 2017).

Nilai perusahaan dipengaruhi oleh faktor internal dan faktor eksternal (Brigham \& Houston, 2015). Faktor internal yaitu keputusan dividen, struktur modal, risiko dan pertumbuhan laba. Struktur modal adalah perbandingan antara modal 
asing (utang jangka panjang) dengan modal sendiri (Riyanto, 2008). Penggunaan utang dalam struktur modal dapat memberikan manfaat berupa penghematan pajak. Semakin besar proporsi utang maka semakin besar perlindungan pajak yang diperoleh, tetapi biaya kebangkrutan yang mungkin timbul juga semakin besar (Hermuningsih, 2013). Pada tingkat utang yang optimal diharapkan nilai perusahaan akan mencapai nilai optimal, dan sebaliknya apabila terjadi tingkat perubahan utang sampai melewati tingkat optimal atau biaya kebangkrutan dan biaya kesulitan keuangan (financial distress cost) lebih besar dari pada efek interest tax-shield, utang akan mempunyai efek negatif terhadap nilai perusahaan (Hermuningsih, 2013).

Struktur modal yang optimal merupakan keseimbangan antara penghematan pajak atas penggunaan utang dengan biaya kesulitan akibat penggunaan utang. Penentuan target struktur modal optimal adalah salah satu dari tugas utama manajemen perusahaan. Struktur modal yang dapat mengoptimalkan nilai perusahaan adalah struktur modal yang terbaik. Indikator untuk menghitung struktur modal perusahaan dapat menggunakan Debt to Equity Ratio (DER). Stuktur modal sebagai faktor yang mempengaruhi nilai perusahaan telah banyak diteliti, hal ini terbukti dengan dilakukannya beberapa penelitian terdahulu pada industri hotel di India (Aggarwal \& Padhan, 2017), perusahaan manufaktur yang terdaftar pada Bursa Efek Instanbul (Demirgüneş, 2017), perusahaan di Vietnam (Vo \& Ellis, 2016), perusahaan pada sektor pertambangan yang terdaftar di Bursa Efek Indonesia (Solikin et al., 2015), perusahaan pada sektor manufaktur yang terdaftar di Bursa Efek Indonesia (Apriada \& Suardikha, 2016; Budiatmo, 2014; A. S. M. Dewi \& Wirajaya, 2013), bank yang terdaftar di Bursa Efek Indonesia (R. P. Dewi, Suhadak, \& Handayani, 2012), perusahaan tekstil yang terdaftar di Bursa Efek Indonesia (Jubaedah, Yulivan, \& Hadi, 2016), dan perusahaanperusahaan lain yang terdaftar di Bursa Efek Indonesia.

Permasalahan nilai perusahaan harus segera diatasi untuk menghindari risiko yang akan terjadi di masa datang yakni berkurangnya investor yang bersedia menanamkan modalnya pada perusahaan subsektor Tekstil dan Garmen. Penelitian ini bertujuan untuk mengetahui gambaran struktur modal dan nilai perusahaan pada subsektor Tekstil dan Garmen periode 20112015.

\section{KAJIAN PUSTAKA}

Keputusan pendanaan merupakan suatu keputusan yang sangat penting bagi perusahaan, karena menyangkut perolehan sumber dana untuk kegiatan operasional perusahaan. Keputusan ini akan berpengaruh terhadap struktur keuangan (financial leverage) dan struktur modal (Riyanto, 2008). struktur modal (capital structure) merupakan pembiayaan pembelanjaan permanen, terutama berupa utang jangka panjang, saham preferen dan modal saham biasa, dalam neraca berada pada posisi sebelah kiri (Hermuningsih, 2013). Struktur modal merupakan rasio yang penting karena di dalamnya mengatur kebutuhan perusahaan, antara memaksimalkan return (meminimalkan biaya modal) dengan kemampuan perusahaan dalam menghadapi lingkungan bisnis yang kompetitif (Mariana, 2014). Struktur modal merupakan kunci perbaikan produktivitas dan kinerja perusahaan (Hermuningsih, 2013) karena struktur modal berkaitan dengan pendanaan untuk kegiatan operasional maupun investasi perusahaan yang berasal dari ekuitas (modal sendiri) dan utang (A. S. M. Dewi \& Wirajaya, 2013).

Risiko yang semakin tinggi akibat membesarnya utang cenderung menurunkan harga saham, sedangkan meningkatkan tingkat pengembalian yang diharapkan akan menaikkan harga saham tersebut. Penentuan target struktur modal optimal adalah salah satu dari tugas utama manajemen perusahaan. Struktur modal yang optimal adalah struktur modal yang mengoptimalkan keseimbangan antara risiko dan pengembalian sehingga memaksimumkan harga saham (Budiatmo, 2014). Aturan struktur finansial konservatif menghendaki agar perusahaan tidak mempunyai utang yang lebih besar daripada jumlah modal sendiri, sedangkan konsep cost of capital menyatakan bahwa perusahaan akan berusaha untuk memperoleh struktur modal yang dapat meminimalkan biaya penggunaan modal rata-rata. Meminimalkan biaya modal rata-rata tidak mengharuskan komposisi jumlah modal eksternal yang lebih sedikit dari jumlah modal sendiri.

Berdasarkan teori struktur modal, apabila posisi struktur modal berada di atas target struktur modal optimalnya, maka setiap pertambahan utang akan menurunkan nilai perusahaan. Struktur modal menunjukkan perbandingan antara modal eksternal jangka panjang dengan modal sendiri, hal ini merupakan aspek yang penting bagi setiap perusahaan karena mempunyai efek langsung terhadap posisi finansial perusahaan. Perusahaan yang memiliki aktiva berwujud cukup besar, cenderung menggunakan utang dalam proporsi yang lebih besar dibandingkan dengan perusahaan yang memiliki aktiva tak berwujud cukup besar meskipun yang terakhir ini memiliki kesempatan tumbuh lebih baik. Ini mudah dipahami karena perusahaan yang hanya memiliki good will namun tidak didukung oleh aktiva berwujud yang cukup, sulit diprediksi prospek kinerjanya 
(Hermuningsih, 2013). Sejumlah faktor mempengaruhi keputusan mengenai struktur modal perusahaan, seperti stabilitas penjualan, struktur aktiva, leverage operasi, peluang pertumbuhan, tingkat profitabilitas, pajak penghasilan, tindakan manajemen dan sebagainya. Faktor-faktor lain yang mempengaruhi struktur modal perusahaan adalah ukuran perusahaan, perusahaan yang lebih besar pada umumnya lebih mudah memperoleh pinjaman dibandingkan dengan perusahaan kecil. Oleh sebab itu dengan memperoleh pinjaman perusahaan dapat berkembang lebih baik lagi (Hermuningsih, 2013). Indikator-indikator dalam menentukan struktur modal yaitu Debt to Asset Ratio (DAR), Debt to Equity Ratio (DER), Long Term Debt to Equity Ratio (LDER), Time Interest Earned, dan Fixed Charge Coverage (FCC) (Kasmir, 2015). Indikator yang digunakan untuk mengukur variabel struktur modal dalam penelitian ini adalah debt to equity ratio (DER). Indikator ini digunakan karena mampu merefleksikan rasio pemenuhan kebutuhan pendanaan perusahaan yang berasal dari utang dibandingkan dengan ekuitas (modal sendiri). Semakin tinggi rasio ini menunjukkan dominasi proporsi utang pada pemenuhan kebutuhan sumber pendanaan dibandingkan dengan modal sendiri dan penerbitan ekuitas (Budiatmo, 2014).

Manajemen keuangan berperan penting dalam mendukung pertumbuhan perusahaan (Dwirachma \& Purnamasari, 2014). Tujuan yang harus dicapai oleh manajer keuangan adalah mengoptimalkan kemakmuran pemilik perusahaan melalui optimasi nilai perusahaan (Sunyoto \& Susanti, 2015). Tujuan untuk mengoptimalkan nilai perusahaan memiliki beberapa keuntungan terutama dalam pembelian perusahaan dan penggabungan perusahaan atau merger (Sunyoto \& Susanti, 2015). Mengoptimalkan nilai perusahaan dinilai lebih tepat sebagai tujuan perusahaan karena berarti mengoptimalkan nilai sekarang dari semua keuntungan yang akan diterima oleh pemegang saham pada masa mendatang atau berorientasi jangka panjang, Mengoptimalkan faktor risiko, lebih menekankan pada arus kas daripada laba menurut pengertian akuntansi, tidak mengabaikan tanggung jawab sosial (Sudana, 2011).

Mengoptimalkan nilai perusahaan tidak identik dengan mengoptimalkan laba per lembar saham (earning per share / EPS). Hal ini disebabkan karena mengoptimalkan EPS mungkin memusatkan pada EPS saat ini, nengoptimalkan EPS mengabaikan nilai waktu uang, Tidak memperhatikan faktor risiko (Sunyoto \& Susanti, 2015). Mengoptimalkan nilai perusahaan tidak identik dengan mengoptimalkan laba, apabila laba diartikan sebagai laba akuntansi, mengoptimalkan nilai perusahaan identik dengan mengoptimalkan laba dalam pengertian ekonomi (economic profit). Hal ini disebabkan karena laba ekonomi diartikan sebagai jumlah kekayaan yang bisa dikonsumsi tanpa membuat pemilik kekayaan tersebut menjadi miskin (Sunyoto \& Susanti, 2015).

Nilai perusahaan yang sudah go public di pasar modal tercermin dalam harga saham (Diani, 2015; Husnan \& Pudjiastuti, 2006), sedangkan perusahaan yang belum go public nilainya terealisasi apabila perusahaan akan dijual dengan mencerminkan nilai aset perusahaan meliputi tingkat risiko usaha, prospek perusahaan, manajemen, lingkungan usaha, dan faktor-faktor lainnya (Mardiyati et al., 2012; Sunyoto \& Susanti, 2015). Kemakmuran pemilik perusahaan bagi perusahaan go public akan meningkat apabila harga saham yang dimilikinya meningkat.

Nilai perusahaan dapat didefinisikan sebagai harga yang bersedia dibayar oleh calon pembeli dan nilai actual per lembar saham yang akan diterima apabila perusahaan akan dijual (Gitman, 2006; Husnan \& Pudjiastuti, 2006; Sunyoto \& Susanti, 2015). Nilai perusahaan merupakan persepsi investor terhadap keberhasilan perusahaan yang berkaitan erat dengan harga saham (Sujoko \& Soebiantoro, 2007). Nilai perusahaan yang tinggi akan memberikan return bagi pemegang saham, sehingga nilai tersebut akan dipandang investor sebagai informasi yang penting dalam mengambil keputusan investasi.

Nilai perusahaan dapat dicerminkan melalui harga saham. Harga saham dapat dikatakan sebagai indikator keberhasilan perusahaan, dimana kekuatan pasar di bursa ditunjukkan dengan adanya transaksi jual beli saham di pasar modal (Kussuma, Surachim, \& Tanuatmodjo, 2016). Pergerakan harga saham selalu berubah-ubah, sehingga diperlukan alat analisis untuk membantu para investor dalam menganalisis dan memilih saham yang akan memberikan return yang tinggi (Purnamasari, 2009). Indikator yang dapat digunakan untuk mengukur nilai perusahaan yaitu Enterprice Value, Price Earning Ratio (PER), Price Book Value (PBV), dan Tobin's Q.

Dalam perusahaan yang menerbitkan saham, umumnya nilai perusahaan diproksi oleh Price Book Value (PBV) (Diani, 2015; Tobing, 2015). PBV dapat digunakan untuk menilai suatu perusahaan karena PBV dapat menggambarkan jumlah apresiasi investor pada saham berdasarkan nilai buku per lembar sahamnya. Ada beberapa keunggulan PBV, yaitu nilai buku merupakan ukuran yang stabil dan sederhana yang dapat dibandingkan dengan harga pasar. Keunggulan kedua adalah PBV dapat dibandingkan antar perusahaan sejenis untuk menunjukkan tanda 
mahal atau murahnya suatu saham. Perusahaan dengan laba negatif, yang tidak dapat dihitung dengan Price Earning Ratio (PER), dapat di evaluasi dengan PBV (Kawito, 2010).

Faktor yang mempengaruhi nilai perusahaan adalah keputusan pendanaan yang terdiri struktur modal dan struktur kepemilikan (L. C. Dewi \& Nugrahanti, 2014; Solikin et al., 2015), selain itu nilai perusahaan dapat dipengaruhi oleh kinerja keuangan yaitu profitabilitas, dan likuiditas (Higgins, 2012; Jayaningrat et al., 2017). Struktur modal merupakan perimbangan antara utang dengan modal sendiri. Penggunaan utang oleh perusahaan dapat memberikan manfaat berupa penghematan pajak yang mampu meningkatkan nilai perusahaan. Pengaruh struktur modal terhadap nilai perusahaan berkaitan dengan tradeoff theory, karena semakin besar proporsi utang maka semakin besar penghematan pajak yang diperoleh, tetapi biaya kebangkrutan yang mungkin timbul juga semakin besar. Struktur kepemilikan yang terdiri dari kepemilikan manajerial dan kepemilikan institusional berpengaruh terhadap nilai perusahaan. Pengaruh tersebut didukung oleh agency theory. Peningkatan kepemilikan saham perusahaan oleh manajemen (kepemilikan manajerial) dapat menurunkan adanya agency cost karena akan mensejajarkan antara kepentingan manajemen dengan pemegang saham. Kepemilikan institusional dapat meningkatkan nilai perusahaan dengan memanfaatkan informasi, serta dapat mengatasi konflik keagenan karena dengan meningkatnya kepemilikan institusional maka seluruh aktivitas perusahaan akan diawasi oleh pihak institusi atau lembaga (Wida \& Suartana, 2014).

Profitabilitas yang tinggi mencerminkan kemampuan perusahaan dalam menghasilkan keuntungan yang tinggi bagi pemegang saham dan berdampak pada kenaikan nilai perusahaan. Aktiva yang digunakan untuk menghasilkan profit adalah aktiva produktif (Surachim \& Anisa, 2010). Profitabilitas menunjukkan apakah badan usaha tersebut mempunyai prospek yang baik di masa yang akan datang (Dintha \& Surachim, 2016). Dengan rasio profitabilitas yang tinggi yang dimiliki sebuah perusahaan akan menarik minat investor untuk menanamkan modalnya di perusahaan (A. S. M. Dewi \& Wirajaya, 2013). Pengaruh likuiditas terhadap nilai perusahaan didukung teori sinyal. Semakin tinggi rasio likuiditas, maka semakin baik reputasi perusahaan, dan akan membuat harga saham meningkat sehingga akan meningkatkan nilai perusahaan.

Untuk mencapai nilai perusahaan yang optimal diperlukan kemampuan dalam mengelola sumber daya keuangan perusahaan yang memadai. Hal tersebut dapat dilihat dari keberhasilan mengelola struktur permodalan yang ditentukan oleh perbandingan hutang jangka panjang dan modal sendiri yang digunakan perusahaan (Dwirachma \& Purnamasari, 2014). Penggunaan utang oleh perusahaan dapat memberikan manfaat berupa penghematan pajak yang mampu meningkatkan nilai perusahaan. Pengaruh struktur modal terhadap nilai perusahaan berkaitan dengan trade-off theory, karena semakin besar proporsi utang maka semakin besar penghematan pajak yang diperoleh, tetapi biaya kebangkrutan yang mungkin timbul juga semakin besar.

Struktur modal haruslah mengoptimalkan nilai perusahaan yang bertujuan demi kepentingan para pemegang saham dan keuntungan yang diperoleh haruslah lebih besar dari biaya modal sebagai akibat penggunaan modal. Semakin besar utang yang digunakan, maka semakin tinggi nilai perusahaan yang berarti semakin tinggi harga sahamnya. Tujuannya adalah karena di Bursa Efek Indonesia bunga utang yang dibayarkan dapat mengurangi pajak yang dibayar oleh perusahaan (Dwirachma \& Purnamasari, 2014).

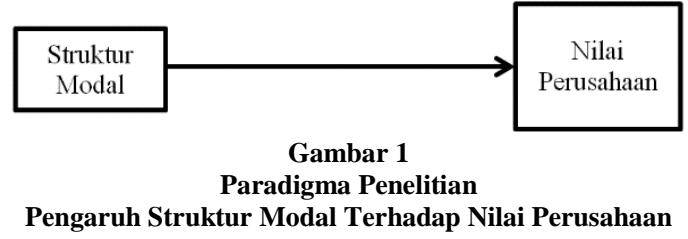

Hipotesis yang akan diuji kebenarannya melalui penelitian ini adalah struktur modal berpengaruh positif terhadap nilai perusahaan.

\section{METODE PENELITIAN}

Penelitian ini dilakukan untuk menganalisis pengaruh struktur modal terhadap nilai perusahaan pada Subsektor Tekstil dan Garmen yang terdaftar di Bursa Efek Indonesia periode 2011-2015. Objek penelitian adalah benda, hal dan sebagainya yang dijadikan sasaran untuk diteliti, diperhatikan, dan sebagainya (www.kbbi.web.id). Objek dalam penelitian ini yaitu struktur modal dan nilai perusahaan. Subjek penelitian adalah orang, tempat, atau benda yang diamati sebagai sasaran (www.kbbi.web.id). Subjek dalam penelitian ini adalah Subsektor Tekstil dan Garmen yang terdaftar di Bursa Efek Indonesia, sedangkan unit analisisnya yaitu fact book Subsektor Tekstil dan Garmen yang terdaftar di Bursa Efek Indonesia selama lima tahun berturut-turut yaitu tahun 2011-2015.

Jenis penelitian yang digunakan adalah penelitian deskriptif dan verifikatif. Penelitian deskriptif merupakan penelitian yang dimaksudkan untuk mengumpulkan informasi mengenai status suatu gejala yang ada, yaitu keadaan gejala menurut apa adanya pada saat penelitian dilakukan (Arikunto, 2013). Penelitian 
deskriptif dalam penelitian ini ditunjukkan untuk mengetahui gambaran mengenai struktur modal dan nilai perusahaan. Penelitian verifikatif adalah jenis penelitian yang bertujuan untuk menguji suatu teori atau hasil penelitian sebelumnya, sehingga diperoleh hasil yang memperkuat atau menggugurkan teori atau hasil penelitian sebelumnya. Penelitian verifikatif ditunjukkan untuk menguji pengaruh struktur modal terhadap nilai perusahaan.

Penelitian ini memiliki variabel-variabel yang akan diteliti yang bersifat saling mempengaruhi. Variabel adalah objek penelitian atau hal yang akan menjadi titik perhatian suatu penelitian (Arikunto, 2013). Terdapat dua variabel dalam penelitian ini, yaitu variabel bebas dan variabel terikat. Variabel bebas (independen) dalam penelitian ini yaitu struktur modal. Struktur modal adalah perbandingan utang dengan modal sendiri yang digunakan untuk menjalankan operasional perusahaan. Indikator yang digunakan untuk mengukur struktur modal adalah Debt to Equity Ratio (DER). Variabel terikat (dependen) dalam penelitian ini yaitu nilai perusahaan. Nilai perusahaan adalah harga yang bersedia dibayar oleh calon pembeli jika perusahaan dijual. Indikator yang digunakan untuk mengukur nilai perusahaan adalah Price Book Value (PBV). Data yang digunakan adalah data dokumenter, karena data yang diperoleh berupa Fact Book Subsektor Tekstil dan Garmen yang terdaftar di Bursa Efek Indonesia periode 2011-2015 dengan Sumber data yang digunakan dalam penelitian ini adalah data sekunder eksternal karena Fact Book dipublikasikan oleh pihak media massa yaitu Bursa Efek Indonesia.

Populasi adalah wilayah generalisasi yang terdiri atas objek/subjek yang mempunyai kualitas dan karakteristik tertentu yang ditetapkan oleh peneliti untuk dipelajari dan kemudian ditarik kesimpulannya (Sugiyono, 2002). Populasi dalam penelitian ini adalah Subsektor Tekstil dan Garmen yang terdaftar di Bursa Efek Indonesia periode 2011-2015 sebanyak 18 perusahaan. Sampel adalah bagian dari jumlah dan karakteristik yang dimiliki oleh populasi (Sugiyono, 2002). Teknik pengambilan sampel dalam penelitian ini adalah purposive sampling, yaitu pemilihan sampel yang didasarkan atas kriteria-kriteria tertentu. Berdasarkan teknik sampling tersebut maka yang menjadi sampel dalam penelitian ini berjumlah 9 perusahaan. Teknik pengumpulan data yang digunakan dalam penelitian ini adalah studi dokumentasi. Studi dokumentasi ialah teknik pengumpulan data dengan mempelajari catatan-catatan mengenai data yang sudah tersedia (Fathoni, 2006). Pelaksanaan teknik dokumentasi ini dilakukan oleh peneliti dengan cara mencari data fact book serta dokumen lain perusahaan Subsektor Tekstil dan Garmen yang terdaftar di Bursa Efek Indonesia periode 2011-2015 yang relevan dengan kepentingan penelitian.

Tahapan yang dilakukan setelah data terkumpul adalah melakukan pengolahan dan menerapkan data sesuai dengan pendekatan penelitian. Data yang akan diolah adalah data fact book Subsektor Tekstil dan Garmen periode 20112015. Teknik analisis data merupakan suatu cara untuk mengukur, mengolah dan menganalisis data tersebut. Tujuan analisis data adalah menyederhanakan atau mengubah ke dalam bentuk yang lebih sederhana untuk lebih mudah dibaca dan diinterpretasikan. Analisis data dimaksudkan untuk melakukan pengujian hipotesis dan menjawab rumusan masalah yang diajukan (Riduwan, 2010).

Analisis data deskriptif berfungsi untuk mendeskripsikan atau memberi gambaran terhadap objek yang diteliti melalui data sampel atau populasi sebagaimana adanya (Sugiyono, 2011). Untuk menghitung nilai struktur modal (varibel X) dan nilai perusahaan (variabel $Y$ ) dilakukan dengan cara mendeskripsikan setiap indikatorindikator variabel tersebut dari hasil pengumpulan yang diperoleh. Analisis verifikatif digunakan untuk menguji hipotesis dengan menggunakan uji statistik dan menitikberatkan pada pengungkapan perilaku variabel penelitian sehingga dapat ditentukan pengaruh variabel bebas struktur modal terhadap variabel terikat nilai perusahaan. Dalam penelitian ini menggunakan analisis regesi linear sederhana. Sebelum melakukan uji regresi terlebih dahulu dilakukan uji asumsi klasik berupa uji normalitas dan uji linearitas.

Uji normalitas bertujuan untuk mengetahui distribusi data pada variabel yang akan digunakan dalam penelitian apakah normal atau tidak (Lubis, 2007). Data yang baik untuk digunakan dalam penelitian adalah data yang terdistribusi normal. Pengujian ini diperlukan karena untuk melakukan uji $t$ dan uji $F$ mengasumsikan bahwa nilai residual mengikuti distribusi normal. Jika asumsi ini dilanggar atau tidak dipenuhi maka uji statistik menjadi tidak valid untuk jumlah sampel kecil (Ghozali, 2016). Pengujian normalitas data pada penelitian ini menggunakan uji Kolmogorov-Smirnov. Jika nilai Asymp.sig > nilai signifikansi $(0,05)$ maka data berdistribusi normal. Uji linearitas bertujuan untuk mengetahui apakah dua varianel mempunyai hubungan yang linear. Uji ini biasanya digunakan sebagai prasyarat dalam analisis korelasi atau regresi linear. Pengujian pada SPSS dengan menggunakan test for linearity dengan pada taraf signifikansi 0,05 .

Untuk mengetahui bagaimana pengaruh kedua variabel, peneliti menggunakan teknik 
Analisis Regresi Linear Sederhana. Analisis regresi linear digunakan untuk mengetahui arah hubungan positif atau negatif antara variabel independen dengan variabel dependen dan untuk memprediksi nilai dari variabel dependen apabila nilai variabel independen mengalami kenaikan atau penurunan. Hipotesis merupakan jawaban sementara terhadap rumusan masalah penelitian, oleh karena itu rumusan masalah penelitian biasanya disusun dalam bentuk kalimat pertanyaan. Hipotesis yang akan diuji dalam penelitian ini adalah struktur modal berpengaruh positif terhadap nilai perusahaan. Pengujian hipotesis dilakukan dengan menguji data yang diperoleh menggunakan uji $\mathrm{F}$ (uji keberartian regresi) dan uji t (uji signifikansi).

\section{HASIL PENELITIAN DAN PEMBAHASAN}

Penelitian mengenai pengaruh struktur modal terhadap nilai perusahaan dilakukan pada 9 perusahaan Subsektor Tekstil dan Garmen sebagai sampel penelitian. Perusahaan-perusahaan tersebut yaitu PT Asia Pacific Investama Tbk, PT Asia Pacific Fibers Tbk, PT Eratex Djaja Tbk, PT Ever Shine Textile Industry Tbk, PT Indo-Rama Synthetics Tbk, PT Nusantara Inti Corpora Tbk, PT Pan Brothers Tbk, PT Polychem Indonesia Tbk, dan PT Star Petrochem Tbk.

Struktur modal adalah perimbangan antara modal asing (utang jangka panjang) dengan modal sendiri. Struktur modal dapat diukur dengan rasio Debt to Equity Ratio (DER), yaitu rasio yang membandingkan antara jumlah utang perusahaan dengan jumlah modal perusahaan. Semakin tinggi DER menunjukkan semakin besar modal pinjaman yang digunakan untuk pembiayaan aktiva perusahaan. Berikut nilai DER pada perusahaan Subsektor Tekstil dan Garmen periode 2011-2015:

\section{Tabel 2}

DER Subsektor Tekstil dan Garmen Periode 2011-2015

\begin{tabular}{clrrrrr}
\hline NO & \multicolumn{1}{c}{ PERUSAHAAN } & $\mathbf{2 0 1 1}$ & $\mathbf{2 0 1 2}$ & $\mathbf{2 0 1 3}$ & $\mathbf{2 0 1 4}$ & $\mathbf{2 0 1 5}$ \\
1 & PT Asia Pacific Investama Tbk. & 27,98 & $-30,60$ & $-21,23$ & $-8,59$ & $-4,42$ \\
2 & PT Asia Pacific Fibers Tbk. & $-1,50$ & $-1,51$ & $-1,43$ & $-1,30$ & $-1,25$ \\
3 & PT Eratex Djaja Tbk. & $-2,76$ & 3,99 & 3,37 & 0,58 & 2,09 \\
4 & PT Ever Shine Textile Industry Tbk. & 1,47 & 1,20 & 1,46 & 1,96 & 3,36 \\
5 & PT Indo--Rama Synthetics Tbk. & 1,28 & 1,32 & 1,47 & 1,44 & 1,71 \\
6 & PT Nusantara Inti Corpora Tbk. & 0,27 & 0,58 & 0,90 & 0,82 & 0,90 \\
7 & PT Pan Brothers Tbk. & 1,21 & 1,43 & 1,36 & 0,79 & 1,05 \\
8 & PT Polychem Indonesia Tbk. & 1,04 & 0,87 & 0,76 & 0,58 & 0,57 \\
9 & PT Star Petrochem Tbk. & 0,47 & 0,54 & 0,53 & 0,58 & 0,49 \\
& Jumlah & 29,46 & -22.18 & -12.81 & -3.14 & 4.5 \\
\hline
\end{tabular}

Sumber: IDX Fact Book, diunduh dari www.idx.co.id (data diolah) Pada tabel 2 dapat dilihat perkembangan penggunaan utang perusahaan Subsektor Tekstil dan Garmen periode 2011-2015 yang diukur dengan rasio DER. PT Asia Pacific Investama Tbk memiliki nilai DER tertinggi pada tahun 2011 sebesar 27,98 yang menunjukkan bahwa total uutang perusahaan lebih tinggi 27,98 kali dibandingkan dengan total modalnya. Pada tahun 2012 hingga 2015 nilai DER pada perusahaan PT Asia Pacific Investama berada pada posisi negatif dikarenakan total modal perusahaan berada pada posisi negatif dan total utang melebihi total modal. PT Asia Pacific Fibers Tbk mengalami hal serupa dengan PT Asia Pacific Investama Tbk yaitu memiliki nilai DER yang negatif selama periode penelitian. Nilai DER yang negatif dialami oleh PT Eratex Djaja Tbk pada tahun 2011 sebesar -2,76 dikarenakan total modal perusahaan yang berada pada posisi negatif. Tahun 2012 hingga 2015 nilai DER PT Eratex Djaja Tbk tidak berada pada posisi negatif, hal ini terjadi karena total modal yang meningkat, namun pada tahun 2012, 2013, dan 2015 total modal tidak melebihi total utang, sedangkan tahun 2014 total modal melebihi total utang.

PT Ever Shine Textile Industry Tbk dan PT Indo-Rama Synthetics Tbk memiliki nilai DER yang meningkat setiap tahunnya, hal ini terjadi karena total utang yang dimiliki perusahaan meningkat setiap tahunnya dan melebihi total modal. PT Nusantara Inti Corpora Tbk memiliki nilai DER yang meningkat setiap tahunnya namun berada di bawah satu, hal ini terjadi karena total modal yang dimiliki perusahaan melebihi total utang. PT Pan Brothers Tbk. mengalami peningkatan DER pada tahun 2011 hingga 2013, namun pada tahun 2014 mengalami penurunan dikarenakan total modal perusahaan melebihi total utang yang dimiliki, tahun 2015 total utang perusahaan meningkat sehingga nilai DER yang dimiliki meningkat.

Berbeda dengan empat perusahaan sebelumnya yang sempat mengalami peningkatan, PT Polychem Indonesia Tbk. justru mengalami penurunan nilai DER setiap tahunnya, hal ini terjadi karena total modal yang dimiliki perusahaan meningkat setiap tahunnya melebihi total utang perusahaan. PT Star Petrochem Tbk. memiliki nilai DER di bawah satu setiap tahunnya karena total modal perusahaan melebihi total utang.

Penelitian pada struktur modal Subsektor Tekstil dan Garmen periode 2011-2015 menunjukkan bahwa terdapat dua perusahaan yang konsisten memiliki struktur modal di atas satu selama periode pengamatan yaitu PT Ever Shine Textile Industry Tbk dan PT Indo-Rama Synthetics Tbk yang berarti bahwa total utang perusahaan lebih besar dibandingkan dengan total modal yang dimiliki perusahaan, selain itu terdapat dua perusahaan yang memiliki nilai DER dengan angka negatif yaitu PT Asia Pacific Investama Tbk dan PT Asia Pacific Fibers Tbk dikarenakan total modal yang dimiliki perusahaan berada dalam kondisi negatif, sedangkan lima perusahaan lain memiliki nilai DER yang bervariatif dengan kecenderungan meningkat pada PT Nusantara Inti Corpora Tbk dan PT Star Petrochem Tbk, serta kecenderungan menurun pada PT Eratex Djaja 
Tbk; PT Pan Brothers Tbk dan PT Polychem Indonesia Tbk.

Tujuan perusahaan yang harus dicapai oleh manajer keuangan adalah mengoptimalkan kemakmuran pemilik perusahaan melalui optimasi nilai perusahaan. Nilai perusahaan dapat diukur dengan rasio Price Book Value (PBV), yaitu rasio yang menggambarkan besarnya pasar menghargai nilai buku saham suatu perusahaan. PBV yang semakin tinggi akan memberikan kepercayaan pasar akan prospek perusahaan tersebut. Berikut nilai PBV pada perusahaan Subsektor Tekstil dan Garmen periode 2011-2015:

Tabel 3

\section{PBV Subsektor Tekstil dan Garmen Periode} 2011-2015

\begin{tabular}{clrrrrr}
\hline NO & PERUSAHAAN & $\mathbf{2 0 1 1}$ & $\mathbf{2 0 1 2}$ & $\mathbf{2 0 1 3}$ & $\mathbf{2 0 1 4}$ & $\mathbf{2 0 1 5}$ \\
1 & PT Asia Pacific Investama Tbk. & 5,17 & $-9,03$ & $-4,32$ & $-0,70$ & $-0,13$ \\
2 & PT Asia Pacific Fibers Tbk. & $-0,15$ & $-0,06$ & $-0,02$ & $-0,02$ & $-0,01$ \\
3 & PT Eratex Djaja Tbk. & $-0,30$ & 0,55 & 0,35 & 0,21 & 0,61 \\
4 & PT Ever Shine Textile Industry Tbk. & 1,25 & 0,91 & 1,04 & 1,33 & 2,02 \\
5 & PT Indo-Rama Synthetics Tbk. & 0,48 & 0,32 & 0,18 & 0,13 & 0,12 \\
6 & PT Nusantara Inti Corpora Tbk. & 0,09 & 0,11 & 0,08 & 0,10 & 0,08 \\
7 & PT Pan Brothers Tbk. & 1,97 & 1,75 & 1,07 & 1,29 & 1,22 \\
8 & PT Polychem Indonesia Tbk. & 0,88 & 0,46 & 0,22 & 0,17 & 0,09 \\
9 & PT Star Petrochem Tbk. & 0,80 & 0,49 & 0,49 & 0,49 & 0,49 \\
& Jumlah & 10,20 & $-4,50$ & $-0,91$ & 3,00 & 4,49 \\
\hline Sumber: IDX Fact Book, diunduh dari www.idx.co.id (data diolah) \\
\multicolumn{5}{c}{ Pada tabel 3 dapat dilihat perkembangan }
\end{tabular}

nilai perusahaan yang diproksikan oleh PBV. PT Asia Pacific Investama Tbk mengalami penurunan PBV yang sangat tajam pada tahun 2012 dengan nilai $-9,03$ dari nilai 5,17 yang diperoleh pada tahun 2011. Pada tahun berikutnya yaitu tahun 2013 hingga 2015 PBV perusahaan tersebut meningkat walaupun masih berada di bawah 0 . Nilai PBV PT Asia Pacific Fibers Tbk mengalami peningkatakan setiap tahunnya walaupun memiliki PBV di bawah 0. PT Eratex Djaja Tbk mengalami peningkatan PBV pada tahun 2012 sebesar 0,55 dari tahun sebelumnya $-0,30$; namun mengalami penurunan selama dua periode yaitu tahun 20132014, dan kembali meningkat pada tahun 2015. Pada tahun 2011 PT Ever Shine Textile Industry Tbk memiliki nilai PBV sebesar 1,25 dan menurun pada tahun 2012 sebesar 0,91 kemudian mengalami peningkatan pada tahun 2013 hingga 2015 dengan masing-masing nilai sebesar 1,04; 1,33; dan 2,02.

PT Indo-Rama Synthetics Tbk dan PT Nusantara Inti Corpora Tbk memiliki nilai PBV di bawah satu selama periode penelitian yaitu tahun 2011-2015, begitu pula dengan PT Polychem Indonesia Tbk dan PT Star Petrochem Tbk, sedangkan PT Pan Brothers Tbk memiliki nilai PBV di atas satu selama periode 2011-2015. Nilai PBV yang dimiliki PT Indo-Rama Synthetics Tbk mengalami penurunan setiap tahunnya, sedangkan PT Nusantara Inti Corpora Tbk mengalami naik turun nilai PBV setiap tahunnya, mulai dari kenaikan pada tahun 2012 menjadi 0,11 dari tahun sebelumnya yang sebesar 0,09 kemudian mengalami penurunan pada tahun 2013 menjadi 0,08 dan kembali meningkat menjadi 0,10 pada tahun 2014 hingga menurun kembali pada tahun 2015 menjadi 0,08. PT Polychem Indonesia Tbk mengalami penurunan nilai PBV setiap tahunnya, sedangkan PT Star Petrochem Tbk mengalami penurunan dari tahun 2011 sebesar 0,80 menjadi 0,49 pada tahun 2012 dan tetap memiliki nilai 0,49 pada tiga tahun berikutnya yaitu tahun 2013,2014 , dan 2015.

Penelitian terhadap nilai perusahaan yang dilakukan pada Subsektor Tekstil dan Garmen periode 2011-2015 menunjukkan bahwa perusahaan yang konsisten memiliki PBV di atas satu selama periode pengamatan adalah PT Pan Brothers Tbk, sedangkan delapan perusahaan lain memiliki PBV yang naik turun hingga mencapai angka negatif.

Uji normalitas dilakukan dengan tujuan untuk menguji apakah data variabel bebas dan data variabel terikat berdistribusi normal. Salah satu bentuk uji normalitas melalui uji KolmogorovSmirnov yang hasil pengujiannya terdapat pada tabel berikut:

Tabel 4

Uji Normalitas dengan Uji KolmogorovSmirnov

One-Sample Kolmogorov-Smirnov Test

\begin{tabular}{|ll|r|}
\hline & & \multicolumn{1}{|c|}{$\begin{array}{c}\text { Unstandardized } \\
\text { Residual }\end{array}$} \\
\hline $\mathrm{N}$ & Mean & 45 \\
Normal Parameters(a,b) & Std. Deviation & .0000000 \\
Most Extreme Differences & Absolute & .65000552 \\
& Positive & .117 \\
& Negative & .117 \\
Kolmogorov-Smirnov Z & & .109 \\
Asymp. Sig. (2-tailed) & & .788 \\
\hline
\end{tabular}

a Test distribution is Normal.

b Calculated from data.

Sumber : Hasil Pengolahan data SPSS

Berdasarkan hasil perhitungan statistik pada tabel 4 yakni untuk menguji normalitas data yang digunakan, diperoleh Asymp.Sig. (2-tailed) yang menunjukkan struktur modal dan nilai perusahaan sebesar 0,564. Nilai Asymp.Sig. lebih besar dari tingkat signifikansi yang ditentukan yaitu 0,05 yang artinya data berdistribusi normal.

Uji linearitas bertujuan untuk mengetahui apakah dua atau lebih variabel mempunyai hubungan yang linear. Perhitungan uji linearitas dalam penelitian ini dilakukan dengan menggunakan bantuan program software SPSS 13 for windows. Adapun hasil yang diperoleh dari pengolahan data tersebut adalah sebagai berikut:

Tabel 5

\section{Uji Asumsi Linearitas} ANOVA Table 


\begin{tabular}{|c|c|c|c|c|c|c|c|}
\hline & & & $\begin{array}{l}\text { Sum of } \\
\text { Squares }\end{array}$ & Df & $\begin{array}{c}\text { Mean } \\
\text { Square }\end{array}$ & $\mathrm{F}$ & Sig. \\
\hline \multirow{5}{*}{$\begin{array}{l}\text { PBV * } \\
\text { DER }\end{array}$} & \multirow{3}{*}{$\begin{array}{l}\text { Between } \\
\text { Groups }\end{array}$} & (Combined) & 148.068 & 39 & 3.797 & 28.869 & .001 \\
\hline & & Linearity & 130.135 & 1 & 130.135 & 989.544 & .000 \\
\hline & & $\begin{array}{l}\text { Deviation } \\
\text { from } \\
\text { Linearity }\end{array}$ & 17.933 & 38 & .472 & 3.588 & .078 \\
\hline & \multicolumn{2}{|c|}{ Within Groups } & .658 & 5 & .132 & & \\
\hline & \multicolumn{2}{|l|}{ Total } & 148.725 & 44 & & & \\
\hline
\end{tabular}

Sumber: Hasil Pengolahan data SPSS

Berdasarkan hasil perhitungan melalui SPSS, diperoleh nilai signifikansi deviation from linearity sebesar 0,078. Nilai tersebut lebih besar dari 0,05, yang artinya terdapat hubungan linear antara variabel struktur modal (X) dengan variabel nilai perusahaan $(\mathrm{Y})$.

Analisis regresi linear sederhana digunakan untuk mengetahui arah hubungan positif atau negatif antara variabel independen dengan variabel dependen dan untuk memprediksi nilai dari variabel dependen apabila nilai variabel independen mengalami kenaikan atau penurunan. Perhitungan regresi linear sederhana dalam penelitian ini dilakukan dengan menggunakan bantuan program software SPSS 13 for windows. Adapun hasil yang diperoleh dari perhitungan tersebut adalah sebagai berikut:

\section{Tabel 6}

Uji Regresi Linear Sederhana Coefficients $^{\text {a }}$

\begin{tabular}{|c|c|c|c|c|c|}
\hline \multirow[b]{2}{*}{ Model } & \multicolumn{2}{|c|}{$\begin{array}{c}\text { Unstandardized } \\
\text { Coefficients }\end{array}$} & \multirow{2}{*}{\begin{tabular}{|c|}
$\begin{array}{c}\text { Standardized } \\
\text { Coefficients }\end{array}$ \\
Beta \\
\end{tabular}} & \multirow[b]{2}{*}{ t } & \multirow[b]{2}{*}{ Sig. } \\
\hline & B & Std. Error & & & \\
\hline (Constant) & .294 & .098 & & 3.004 & .004 \\
\hline DER & .235 & .014 & .935 & 17.350 & .000 \\
\hline
\end{tabular}

Tabel 6 menunjukkan hasil uji regresi linear sederhana dan diperoleh persamaan regresi antara DER dengan PBV sebagai berikut:

$\mathrm{Y}=\mathrm{a}+\mathrm{bX}$

$\mathrm{Y}=0,294+0,235 \mathrm{X}$

a. Konstanta sebesar 0,294 menyatakan bahwa jika DER tidak mengalami perubahan maka nilai PBV adalah sebesar 0,294

b. Nilai koefisien regresi struktur modal (DER) sebesar 0,235; nilai ini menunjukkan bahwa setiap peningkatan struktur modal (DER) sebesar 1\%, maka nilai perusahaan (PBV) akan bertambah sebesar 0,235 kali.

Pada persamaan regresi di atas, koefisien regresi tersebut bernilai positif. $\mathrm{Hal}$ ini menggambarkan pengaruh positif antara variabel struktur modal (X) dengan variabel nilai perusahaan (Y), artinya bahwa setiap adanya kenaikan struktur modal maka nilai perusahaan perusahaan akan meningkat, sebaliknya apabila struktur modal menurun maka nilai perusahaan akan menurun.

Pengujian hipotesis dengan uji $\mathrm{F}$ adalah untuk menguji keberartian regresi, dilakukan dengan menggunakan tabel $F$ atau uji ANOVA dengan membandingkan $\mathrm{F}_{\text {hitung }}$ dan $\mathrm{F}_{\text {tabel }}$ hipotesis statistik.

Rumusan hipotesis:

$\mathrm{H}_{0}$ : regresi tidak berarti

$\mathrm{H}_{1}$ : regresi berarti

Dengan kriteria penerimaan dan penolakan sebagai berikut:

Jika $\mathrm{F}_{\text {hitung }} \leq \mathrm{F}_{\text {tabel }}$ maka $\mathrm{H}_{0}$ diterima dan $\mathrm{H}_{1}$ ditolak Jika $\mathrm{F}_{\text {hitung }}>\mathrm{F}_{\text {tabel }}$ maka $\mathrm{H}_{0}$ ditolak dan $\mathrm{H}_{1}$ diterima Berikut hasil pengujian hipotesis berdasarkan perhitungan SPSS:

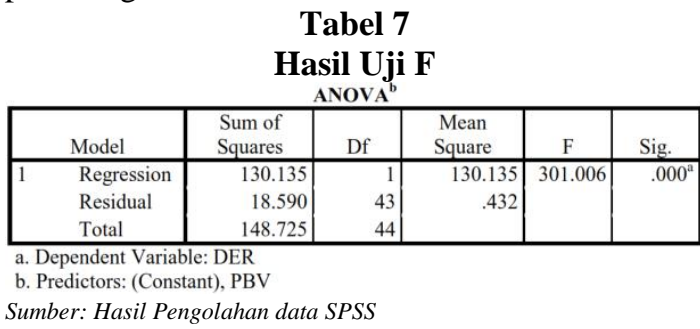

Hasil perhitungan pada tabel ANOVA di atas menunjukkan bahwa nilai $F_{\text {hitung }}$ yang diperoleh dari hasil uji statistik adalah 301,006. Sedangkan $F_{\text {tabel }}$ yang diperoleh pada tingkat signifikansi 0,05 dengan $\mathrm{df}_{1}=1$, dan $\mathrm{df}_{2}=43$ adalah 4,07 . Perbandingan yang dilakukan antara $F_{\text {hitung }}$ dengan $F_{\text {tabel }}$ menghasilkan $F_{\text {hitung }}>F_{\text {tabel }}$ atau 301,006 > 4,07, maka kesimpulan yang diperoleh adalah $\mathrm{H}_{0}$ ditolak atau regresi berarti.

Selain uji $\mathrm{F}$ perlu juga dilakukan uji $\mathrm{t}$ yang digunakan untuk mengetahui pengaruh antara variabel bebas terhadap variabel terikat. Pengujian pada penelitian ini digunakan uji satu pihak kanan dengan tingkat signifikansi 0,05 .

$\mathrm{H}_{0}: \beta=0$, tidak terdapat pengaruh struktur modal terhadap nilai perusahaan

$\mathrm{H}_{1}: \beta>0$, terdapat pengaruh positif struktur modal terhadap nilai perusahaan

Dengan kriteria penerimaan dan penolakan sebagai berikut:

Jika $\mathrm{t}_{\text {hitung }} \leq \mathrm{t}_{\text {tabel }}$ maka $\mathrm{H}_{0}$ diterima $\mathrm{H}_{1}$ ditolak

Jika $t_{\text {hitung }}>\mathrm{t}_{\text {tabel }}$ maka $\mathrm{H}_{0}$ ditolak $\mathrm{H}_{1}$ diterima

Tabel 8

Hasil Uji T

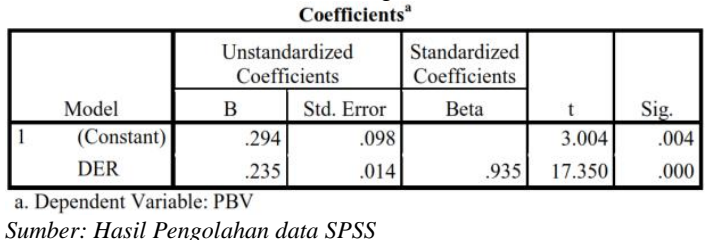

Hasil uji t menunjukkan bahwa nilai $t_{\text {hitung }}$ sebesar 17,350 sedangkan $t_{\text {tabel }}$ dalam penelitian ini adalah 1,68107 dengan demikian maka $t_{\text {hitung }}$ $(17,350)>t_{\text {tabel }}(1,68107)$. Kesimpulan yang dapat diambil adalah $\mathrm{H}_{0}$ ditolak dan $\mathrm{H}_{1}$ diterima yang artinya terdapat pengaruh positif struktur modal terhadap nilai perusahaan pada Subsektor Tekstil dan Garmen periode 2011-2015, hal ini menunjukkan bahwa hipotesis yang diajukan penulis diterima. 
Berdasarkan hasil persamaan regresi diperoleh $\mathrm{Y}=0,294+0,235 \mathrm{X}$, dimana setiap peningkatan struktur modal (DER) sebesar $1 \%$ maka nilai perusahaan (PBV) akan bertambah sebesar 0,235 kali, dan apabila struktur modal tidak mengalami perubahan maka nilai perusahaan akan bernilai 0,294. Koefisien regresi pada hasil persamaan regresi adalah positif, hal tersebut menggambarkan bahwa struktur modal yang diukur menggunakan Debt to Equity Ratio (DER) berpengaruh positif terhadap nilai perusahaan yang diukur menggunakan Price Book Value (PBV), sehingga hipotesis yang diajukan penulis yaitu terdapat pengaruh positif struktur modal terhadap nilai perusahaan sesuai dan dapat diterima.

Hasil penelitian ini mendukung penelitian yang dilakukan oleh Hermuningsih (2013); Solikin, dkk (2015); Dewi, dkk (2012); dan Jubaedah, dkk (2016); yang menunjukkan bahwa setiap adanya kenaikan struktur modal maka nilai perusahaan akan meningkat sebaliknya apabila struktur modal menurun maka nilai perusahaan akan menurun.

\section{KESIMPULAN DAN REKOMENDASI}

Berdasarkan penelitian dan pembahasan serta hipotesis yang telah disusun dan telah di uji pada bagian sebelumnya, maka dapat disimpulkan pengaruh struktur modal terhadap nilai perusahaan pada subsektor tekstil dan garmen, adalah sebagai berikut:

1. Gambaran struktur modal yang diukur dengan menggunakan rasio DER (Debt to Equity Ratio) pada subsektor tekstil dan garmen periode tahun 2011-2015 memiliki nilai yang bervariatif dengan kecenderungan meningkat.

2. Gambaran nilai perusahaan yang diukur dengan menggunakan rasio PBV (Price Book Value) pada subsektor tekstil dan garmen periode tahun 2011-2015 menunjukkan nilai PBV yang fluktuatif dengan kecenderungan meningkat setiap tahunnya.

3. Berdasarkan pengujian hipotesis diperoleh hasil bahwa struktur modal berpengaruh positif terhadap nilai perusahaan.

Berdasarkan hasil penelitian yang telah dilakukan mengenai pengaruh struktur modal dengan indikator DER terhadap nilai perusahaan dengan indikator PBV pada subsektor Tekstil dan Garmen periode 2011-2015, penulis mengajukan beberapa saran yang dapat dijadikan bahan pertimbangan bagi manajemen pada subsektor Tekstil dan Garmen. Berdasarkan kesimpulan di atas, maka beberapa saran yang mungkin dapat diajukan adalah sebagai berikut:

1. Perusahaan hendaknya senantiasa menjaga struktur modal optimal dengan mengoptimalkan penggunaan utang agar tidak mencapai extreme leverage dan meminimalkan biaya keagenan yang ditimbulkan.

2. Perusahaan hendaknya senantiasa meningkatkan nilai perusahaan dengan mengoptimalkan penggunaan utang sehingga memperoleh struktur modal optimal, selain itu perlu juga mempertimbangkan adanya kepemilikan institusional dalam struktur kepemilikan perusahaan sebagai pihak yang mengawasi perusahaan maupun manajer dan dapat mengatasi konflik keagenan.

3. Untuk peneliti selanjutnya yang tertarik meneliti pengaruh struktur modal terhadap nilai perusahaan, disarankan juga meneliti faktor-faktor lainnya yang mempengaruhi nilai perusahaan seperti struktur kepemilikan, profitabilitas, dan likuiditas atau menambah periode pengamatan dan meneliti subsektor lainnya.

\section{DAFTAR PUSTAKA}

Aggarwal, D., \& Padhan, P. C. (2017). Impact of Capital Structure on Firm Value : Evidence from Indian Hospitality Industry. Theoretical Economics Letters, 7, 9821000.

Al-Najjar, B. A.-N. D. (2017). The Impact of External Financing on Firm Value and a Corporate Governance Index: SME Evidence. Journal of Small Business and Enterprise Development, 24(2).

Apriada, K., \& Suardikha, M. S. (2016). Pengaruh Struktur Kepemilikan Saham, Struktur Modal dan Profitabilitas pada Nilai Perusahaan. E-Jurnal Ekonomi Dan Bisnis Universitas Udayana, 5(2), 201-218.

Ararat, M., Black, B. S., \& Yurtoglu, B. B. (2016). The Effect of Corporate Governance on Firm Value and Profitability: Time-Series Evidence from Turkey. Emerging Markets Review.

Arikunto, S. (2013). Manajemen Penelitian (Edisi Revi). Jakarta: Rineka Cipta.

Brigham, E. F., \& Houston, J. F. (2015). Fundamentals of Financial Management (8th ed.). USA: Cengage Learning.

Budiatmo, A. (2014). Pengaruh Struktur Modal terhadap Nilai Perusahaan Studi Kasus Perusahaan Manufaktur yang Tercatat di BEJ tahun 2008-2011. Jurnal Ilmu Sosial, 13(1).

Darmadji, T., \& Fakhruddin, H. M. (2011). Pasar Modal di Indonesia (3rd ed.). Jakarta: Salemba Empat.

Davis, A., Moore, R., \& Rupert, T. (2016). The Effect of Tax Expense Management and CSR Ratings on Investor Perceptions of Firm Value. 
Demirgüneş, K. (2017). Capital Structure Choice and Firm Value: New Empirical Evidence from Asymmetric Causality Test. International Journal of FInancial Research, 8(2), 75-91.

Dewi, A. S. M., \& Wirajaya, A. (2013). Pengaruh Struktur Modal, Profitabilitas dan Ukuran Perusahaan pada Nilai Perusahaan. E-Jurnal Akuntansi Universitas Udayana, 4(2), 358372.

Dewi, L. C., \& Nugrahanti, Y. W. (2014). Pengaruh Struktur Kepemilikan dan Dewan Komisaris Independen Terhadap Nilai Perusahaan (Studi pada Perusahaan Industri Barang Konsumsi di BEI Tahun 20112013). Jurnal Kinerja, 18(1), 64-79.

Dewi, R. P., Suhadak, \& Handayani, S. R. (2012). The Effects of Capital Structure and Good Corporate Governance on Dividend Policy and Firm Value.

Diani, A. F. (2015). Pengaruh Kebijakan Dividen, Kebijakan Hutang dan Profitabilitas Terhadap Nilai Perusahaan. E-Jurnal Riset Manajemen.

Dintha, R., \& Surachim, A. (2016). Pengaruh Capital Structure Dan Working Capital Management terhadap Profitabilitas. Journal of Business Management and Enterpreneurship Education, 1(1), 42-46.

Du, J., Wu, F., \& Liang, X. (2016). Corporate liquidity and firm value: evidence from China's listed firms, 3, 4-7.

Dwirachma, A., \& Purnamasari, I. (2014). Pengaruh Struktur Modal Terhadap Nilai Perusahaan Asuransi Yang Listing Di Bursa Efek Indonesia. Antologi Pendidikan Akuntansi Dan Keuangan, 2(2).

Fathoni, A. (2006). Metodologi Penelitian \& Teknik Penyusunan Skripsi. Jakarta: Rineka Cipta.

Ghozali, I. (2016). Aplikasi Analisis Multivariate dengan Program IBM SPSS 23. Semarang: Universitas Dipenogoro.

Gitman, L. J. (2006). Principles of Managerial Finance (11th ed.). Boston: Addison Wesley.

Hermuningsih, S. (2013). Pengaruh Profitabilitas, Growth Opportunity, Sruktur Modal Terhadap Nilai Perusahaan Pada Perusahaan Publik di Indonesia. Buletin Ekonomi Moneter Dan Perbankan.

Higgins, R. C. (2012). Analysis For Financial Management (10th ed.). New York: The McGraw-Hill.

Husnan, S., \& Pudjiastuti, E. (2006). Dasar-dasar Manajemen Keuangan (Edisi Keli). Yogyakarta: UPP STIM YKPN.

Jayaningrat, I. G. A. A., Wahyuni, M. A., \& Sujana, E. (2017). Pengaruh Leverage,
Profitabilitas, Likuiditas, Kebijakan Dividen, Kepemilikan Manajerial dan Kepemilikan Institusional terhadap Nilai Perusahaan pada Perusahaan Properti dan Real Estate di Bursa Efek Indonesia tahun 2013-2015. E-Journal S1 AK Universitas Pendidikan Ganesha, 7(1).

Jubaedah, Yulivan, I., \& Hadi, A. R. (2016). The Influence of Financial Performance, Capital Structure and Macroeconomic Factors on Firm's Value - Evidence from Textile Companies at Indonesia Stock Exchange. Applied Finance and Accounting, 2(2), 1829.

Kasmir. (2015). Pengantar Manajemen Keuangan (Edisi Kedu). Jakarta: Prenadamedia Grup.

Kawito, P. (2010). Menggunakan Peta PBV - ROE Untuk Investasi Saham. Infovesta.com, 1-3.

Khan, A., Tanveer, S., \& Malik, U. (2017). An empirical analysis of corporate governance and firm value: Evidence from KSE-100 Index, 3, 119-130.

Kussuma, P., Surachim, A., \& Tanuatmodjo, H. (2016). Dampak Tingkat Profitabilitas Dan Nilai Pasar Pada Pergerakan. Journal of Business Management Education, 1(2), 97103.

Lubis, A. F. (2007). Aplikasi SPSS (Statistical Product and Service Solutions) untuk penyusunan skripsi \& tesis. Medan: USU Press.

Mardiyati, U., Ahmad, G. N., \& Putri, R. (2012). Pengaruh Kebijakan Dividen, Kebijakan Hutang dan Profitabilitas Terhadap Nilai Perusahaan Manufaktur yang Terdaftar di Bursa Efek Indonesia (BEI) Periode 20052010. Jurnal Riset Manajemen Sains Indonesia, 3(1), 1-17.

Mariana, R. (2014). Pengaruh Capital Structure Terhadap Profitabilitas. Bandung.

Nesbitt, W. L., Outslay, E., \& Persson, A. (2017). The Relation Between Tax Risk and Firm Value: Evidence From The Luxembourg Tax Leaks, (2016).

Nguyen, T., Duong, H. N., \& Singh, H. (2016). Stock market Liquidity and Firm Value: An Empirical Examination of the Australian Market. International Review of Finance, (2001), 1-11. https://doi.org/10.1111/ir

Purnamasari, I. (2009). Pengaruh Kinerja Perusahaan terhadap Return Saham. Jurnal Akuntansi Riset.

Riduwan. (2010). Dasar-dasar Statistika. Bandung: Alfabeta.

Riyanto, B. (2008a). Dasar-dasar Pembelajaan Perusahaan (3rd ed.). Yogyakarta: BPFE UGM.

Riyanto, B. (2008b). Dasar-dasar Pembelanjaan Perusahaan. Yogyakarta: Penerbit GPFE. 
Seth, R., \& Mahenthiran, S. (2016). Impact of Dividends, Corporate Social Responsibility, and Ownership on Firm Value - Evidence from India. 6th Annual International Conference on Accounting and Finance.

Simatupang, M. (2010). Pengetahuan Praktis Investasi Saham dan Reksa Dana. Jakarta: Mitra Wacana Media.

Solikin, I., Widaningsih, M., \& Lestari, S. D. (2015). Pengaruh Struktur Kepemilikan, Struktur Modal, dan Ukuran Perusahaan Terhadap Nilai Perusahaan pada Perusahaan Sektor Pertambangan yang Terdaftar di Bursa Efek Indonesia. Jurnal Riset Akuntansi Dan Keuangan, 3, 774-790.

Su, K., Li, L., \& Wan, R. (2016). Ultimate ownership, risk-taking and firm value: evidence from China. Asia Pacific Business Review. https://doi.org/10.1080/13602381.2016.115 2021

Sudana, I. M. (2011). Manajemen Keuangan Perusahaan Teori dan Praktik. Jakarta: Erlangga.

Sugiyono. (2002). Metode Penelitian Bisnis. Bandung: Alfabeta.

Sugiyono. (2011). Statistika untuk Penelitian. Bandung: Alfabeta.

Suharli, M. (2006). Studi Empiris Terhadap Faktor yang Mempengaruhi Nilai Perusahaan pada Perusahaan Go Public di Indonesia. Jurnal Manajemen Akuntansi, 6.

Sujoko, \& Soebiantoro, U. (2007). Pengaruh Struktur Kepemilikan Saham, Leverage, Faktor Intern Dan Faktor Ekstern Terhadap Nilai Perusahaan (Studi empirik pada perusahaan manufaktur dan non manufaktur di Bursa Efek Jakarta). Jurnal Manajemen Dan Kewirausahaan, 9(1), 41-48.

Sulong, Z., \& Nor, F. M. (2008). Dividends , Ownership Structure and Board Governance on Firm Value : Empirical Evidence From. Malaysian Accounting Review, 7(2).

Sunyoto, D., \& Susanti, F. E. (2015). Manajemen Keuangan untuk Perusahaan. Yogyakarta: CAPS (Center of Academic Publishing Service).

Surachim, A., \& Anisa, D. (2010). Pengaruh Penyaluran Kredit (Loan) Terhadap Profitabilitas (Studi Kasus pada Laporan Keuangan PT Bank Mega Tbk). Strategic, 9(18), 40-57.

Suta, I. W. P., Agustina, P. A. A., \& Sugiarta, I. N. (2016). Pengaruh Kebijakan Utang pada Nilai Perusahaan dengan Kepemilikan Institusional sebagai Variabel Moderasi. Jurnal Bisnis Dan Kewirausahaan, 12(3), 173-185.
Tobing, R. L. (2015). Efek Mediasi Kebijakan Dividen pada Pengaruh Gugus Kesempatan Investasi (IOS) Terhadap Rasio Hutang dan Nilai Perusahaan. Jurnal Ilmiah Manajemen Bisnis, 15.

Vo, X. V., \& Ellis, C. (2016). An Empirical Investigation of Capital Structure and Firm Value in Vietnam. Finance Research Letters.

Wida, N. P., \& Suartana, I. W. (2014). Pengaruh Kepemilikan Manajerial dan Kepemilikan Institusional Pada Nilai Perusahaan. EJurnal Akuntansi Universitas Udayana, 3, 575-590.

Widyastuti, P., Suhadak, Musadieq, M. Al, \& Hsu, W.-H. L. (2016). The Influence of Financial Performance and Dividend Policy on Firm Value. Journal of Business Studies, 2(1). Retrieved from http://jbsq.org/wpcontent/uploads/2012/12/Dec_2012_9.pdf

Zulfikar. (2016). Pengantar Pasar Modal dengan Pendekatan Statistika (Edisi Pert). Yogyakarta: Deepublish. 